\title{
Wear Mechanisms applied to Lifeboat Slipway Launches
}

\author{
B. Thomas* $*^{1}$, M. Hadfield ${ }^{1}$, S. Austen ${ }^{2}$, \\ ${ }^{1}$ Sustainable Design Research Centre, Bournemouth University, UK, \\ ${ }^{2}$ Royal National Lifeboat Institution, Poole, UK.
}

Received --/--/-- accepted --/--/--

\begin{abstract}
It is necessary to use an inclined slipway to launch a large lifeboat in locations where there is no natural harbour or where there is a large tidal range. Slipway stations consist of an initial section where the boat is held on rollers followed by an inclined keelway of nickel/chromium coated steel, the lifeboat is released from the top of the slipway and proceeds under its own weight into the water. The lifeboat is subsequently recovered to the top of the slipway using a winch line. With the introduction of the new, larger Tamar class lifeboat existing boathouses are being upgraded and existing low friction coated steel slipway lining materials replaced with a low-friction jute fibre/phenolic resin composite, which is designed to operate with unlubricated conditions. This has led to problems of high wear on slipway panels, particularly where the lifeboat mounts the slipway for recovery.
\end{abstract}

This paper describes a method for assessing slipway lining materials and lubricants. The selection of an appropriate test machine, the TE92 rotary tribometer, and design of a modified ring on disc arrangement incorporating panel interfaces and attaching holes effects is described. An experimental methodology is developed using programmed running intervals to simulate dwell effects.

Experimental data is thus presented to establish slipway panel wear rates for a range of lubricants and contact pressures. Experimental results are incorporated into real-world slipway surveys to develop the wear scenario. Results and implications of this research for future lifeboat slipway design are discussed.

Keywords: Sliding Wear, Lifeboat, Slipway.

\section{Introduction}

The RNLI was established in 1824 to provide search and rescue cover along the coast of the UK and Ireland. Currently a number of different boats and launching options are used to provide this cover, the most famous of which is the slipway launched lifeboat. In this case the lifeboat launches down an inclined slipway usually consisting of an upper section of steel rollers and a lower, plain section lined with low friction materials. The lifeboat is later recovered to the top of the slipway using manoeuvring buoys for alignment and a winch attached to the rear of the keel. In order to ensure low friction during launch and recovery it is usual to apply a lubricant to the slipway. With the introduction of the new, heavier Tamar class slipway lifeboat and the corresponding construction of larger boathouses and slipways to accommodate the craft, issues of high friction and wear along the plain sliding section of the slipway have become important, particularly during the recovery phase where high winch loadings due to friction can seriously reduce the winch's life. Wear issues with the new graphite infused jute/phenolic composite lining have also been noted, with the lining degrading rapidly during use. Similar problems are observed on older launch slipways and strategies to reduce these effects have been developed on a site specific basis. The aim of this research is to develop a standard procedure to prevent occurrences of high friction and minimise wear.

\footnotetext{
* Corresponding author. Tel. +44 1202524111

E-mail Address: thomasb@bournemouth.ac.uk (B. Thomas)
}

2. Current Slipway Lubricants and linings used by the RNLI Currently it is usual to apply lubricant to the lined section of the slipway before launch and recovery to ensure smooth travel. The lubricant used and frequency of application vary somewhat between slipway stations but the most common lubricant used is a general purpose marine grease designed to be used in environments where seawater, freshwater or condensation moisture may contaminate the system. Other notable lubricants are a silicon microball infused lubricant, which was originally designed as a cable pulling lubricant and includes silicone microspheres. This lubricant is used at Sennen Cove which has a particularly shallow incline to its launch slipway. The Tamar equipped slipway stations at Tenby and Padstow are experimenting with freshwater as a lubricant, this is run from pipes at the top of the slipway.

There are a number of different slipway linings used on RNLI slipway stations, in most cases these are installed as and when friction or wear problems occur. The traditional slipway lining material is weather treated wood, and it is usual to apply grease to this material. Following the introduction of the heavier Tyne lifeboat from 1982 the majority of these traditionally lined slipways were re-lined with steel plate featuring a nickel/chromium carbide coating designed for low friction and high wear resistance. As problems with high friction persisted on some slipways a graphite infused jute/phenolic resin composite material was introduced, this initially proved very successful, but problems with durability soon led to a change from a $6 \mathrm{~mm}$ section to a thicker $19 \mathrm{~mm}$ 
section. The graphite infused jute/phenolic lining is now the preferred lining for all slipway refurbishments and new slipways as many are re-built to accommodate the Tamar class lifeboat. The composite lining was originally intended to be used dry, without lubrication, but persisting problems with friction have led many slipway stations to continue to use marine grease lubrication. The use of marine grease along the slipway has led to concerns for the environmental impact of this practice as the grease is washed into the sea immediately around the slipway exit and may have the potential to bioaccumulate. With this in mind the substitution of marine grease and other lubricants currently used with a more ecofriendly alternative has been proposed.

Friction problems along the slipway usually manifest during recovery, when the hauling winch loads can increase, in some cases beyond the specification of the winch. This can lead to drastically reduced hauling speeds and shortened winch life. The application of lubricant along the slipway before recovery does reduce this effect but this can be unreliable as inconsistent application and included environmental debris (e.g. wind-blown sand) can make the lubrication regime unpredictable. High friction on launch presents fewer problems but can result in reduced launch speeds and even seizure. Again, the manual application of lubricant along the slipway before launch is usual and this also involves safety issues due to the exposed nature of the slipway and the weather conditions usually present during a lifeboat callout.. Friction problems have also been observed with the graphite infused jute/phenolic lining at the new boathouses at Padstow and Tenby, which also feature new slipways specially designed for the Tamar class lifeboat.

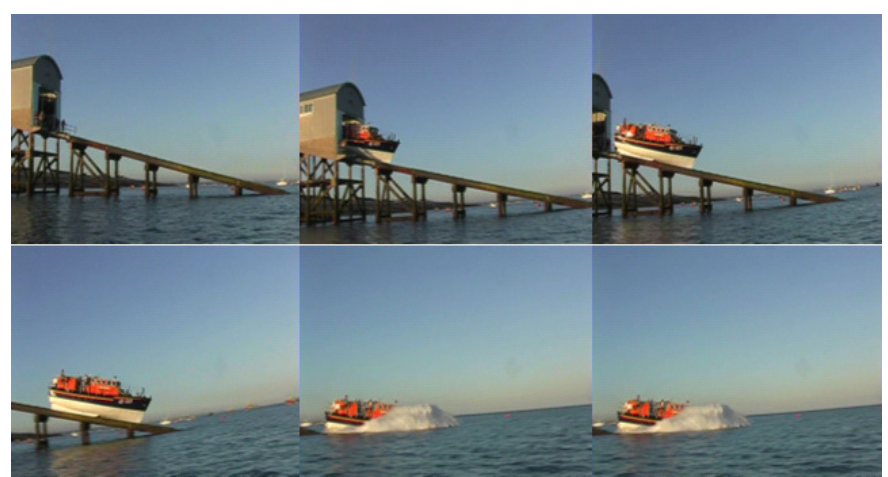

Fig. 1. Typical slipway launch: Tyne class lifeboat at Selsey moves down the plain sliding section of the slipway under its own weight

Wear on the slipways is also significant. The older treated wood and low friction coated steel lined slipways experienced relatively light wear during service but the new graphite infused jute/phenolic composite has been seen to wear rapidly, and this has led to shorter replacement intervals and reduced efficiency. The wear problem is of particular concern where the composite is used on the new boathouses and slipways for the Tamar class lifeboat at Tenby and Padstow, both these stations have shown significant cracking and degrading of the slipway lining during their short active use resulting in a service life reduction from two years to two weeks for some panels.

It is against this background that the following research was commissioned, with the aim of reducing the wear rates of the composite panels to acceptable levels.

\section{Previous work}

There has as yet been very little specific research into lifeboat slipway wear, although the wear of plane sliding systems has been heavily documented. The friction along slipways used for ship launch has also been investigated ${ }^{1,2}$, though the single use nature of these systems is an important differentiating factor with regard to the lifeboat slipway case. Internal RNLI slipway line trials ${ }^{3-10}$ are used to assess the friction performance of lifeboat slipways under recovery conditions at regular intervals and these have indicated a variety of friction behaviours using the jute/phenolic composite at a number of slipway stations.

A Previous study ${ }^{11}$ conducted by Newcastle University, commissioned by the RNLI, investigated friction and wear characteristics of various lifeboat keel materials. The aim of this research was to investigate the feasibility of using composite rather than steel keels to reduce the weight of slipway launched lifeboats. Reducing the weight of the lifeboat would consequently reduce the force required to recover the lifeboat onto the slipway and increase the speed. The study compared the friction of conventional keel materials on steel slipways with some composite keel materials, namely glass reinforced Ampreg 26, Kevlar reinforced Ampreg 26, a glass/Kevlar hybrid reinforced Ampreg 26, and a glass reinforced vinyl ester. The study used a pin on disc style tribometer, with the pin representing the steel slipway. Tests were performed dry and with seawater present and the results recorded. Ultimately, though the wear rate proved acceptable in many cases, the friction generated with the new keel materials was too high to be practical and presented greater risk of 'sticking' on the slipway during launch and recovery.

Following this research a second series of tests ${ }^{12}$ was conducted in a similar fashion to investigate a further series of potential keel materials, this time with a number of low friction additives included. Again, it was found that the friction coefficient was too high and that most of the intended low friction additives served to increase rather than decrease the friction. The only material found to perform well in both friction and wear was a glass reinforced phenolic composite and the study concludes by suggesting that this may be a suitable material for further testing, including the possibility of low friction inclusions or coatings to further reduce the friction coefficient. Ultimately, the composite keel concept was abandoned but the promise of phenolic composites was duly noted and influenced the decision to replace the steel slipway lining sections with a graphite infused jute fibre/phenolic resin composite as, and when problems of high friction occurred.

A series of screening tests using a modified TE57 reciprocating tribometer ${ }^{13}$ incorporating various lubrication regimes and contact pressures were conducted at the outset of this work. The TE57 is a tribometer designed to provide an accelerated method for assessing friction and wear between pin and plate materials under various tribological conditions. It was developed and subsequently modified to include a pressure chamber and a greater range of lubricant regime testing by Plint Tribology. A pin, actuated by a motor reciprocates at up to $50 \mathrm{~Hz}$ with a stroke length of up to $5 \mathrm{~mm}$. The specimen is attached below the pin and a contact force of up to $50 \mathrm{~N}$ is applied using a spring loaded lever arrangement. The specimen sits in a bath that can be used to hold the 
lubricant when testing lubricated friction scenarios. The friction force on the sample is recorded using a force transducer in series with the horizontal actuating ram. The signal from the transducer is recorded throughout the stroke and in this way the friction coefficient between the pin and specimen can be calculated. The velocity of the motion and test duration is set by an electronic controller.

The contact geometry was modified from the original cylinder on plate or ball on plate arrangement to a pin on plate arrangement using a specially designed self-levelling $\operatorname{pin}^{13}$ in order to simulate the plane sliding encountered in realworld slipways.

Tests were conducted for a duration of 10 hours and a total sliding distance of $9 \mathrm{~km}$ in order to simulate the sliding during the expected two year lifespan of the slipway panels. The tests provided useful data on the expected friction and wear on the slipway panels as well as wear mechanisms and lubrication effects. It was found that the wear coefficients measured were uniformly low and would not result in sufficient wear to cause panel failure under normal circumstances.

Following these initial tests a second, more detailed series of wear tests were commissioned.

\section{Test Methodology}

In order to develop a suitable test geometry for more detailed slipway panel wear modelling it is necessary to incorporate real-world effects such as the dwell time between launch and recovery, the nature of the plane sliding contact and the geometry of the slipway panels themselves. It is decided to investigate these using a specially modified TE92 rotary tribometer.

The TE92 is a rotary tribometer made by Plint Tribology and capable of using a number of pin/disc combinations. The tribometer uses a pneumatic ram to bring a pin and sample into contact at a set contact pressure and then rotates the pin on the sample at a set or variable speed. The controller can also be programmed to stop the motor and restart at any time. Following the test the sample is inspected for wear either using mass loss techniques or visual inspection.

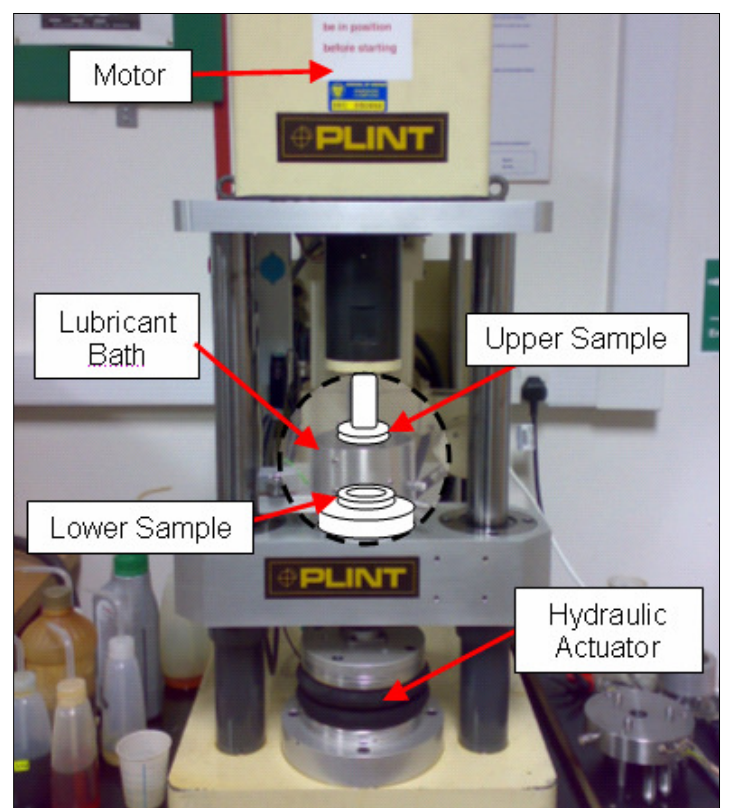

Fig. 2. Plint TE92 Rotary Tribometer with Test Sample Schematic

\section{Contact Geometry Design}

The contact geometry was chosen to most closely mirror the real-world case and is based on a ring on disc geometry. This effectively mimics the conditions of plane sliding on the real-world slipway.

In order to incorporate the effects of the geometric features present on the slipway panels into the test, these features are included on the test specimen. A small slot is cut radially in the sample to simulate the edge stresses present in the panel interfaces and a small $2.5 \mathrm{~mm}$ dia. hole is drilled in the specimen to mimic the geometric stresses present around the fixing holes of the slipway panels.

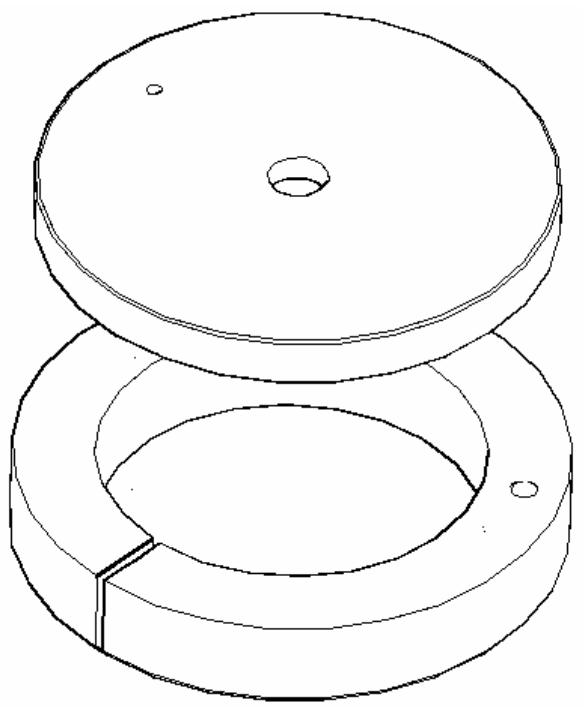

Fig. 3. Plint TE92 Modified Ring on Disc Configuration

\section{Test Parameters}

For these tests the appropriate contact force and rotational speed must be chosen to match the real-world case, here, a contact force of $20 \mathrm{~N}$ generates the same contact pressure as the 35 tonne Tamar lifeboat resting on a $1.92 \mathrm{~m}^{2}$ keel contact area and a rotation speed of 176RPM corresponds to the recommended $15 \mathrm{~m} / \mathrm{min}$ line speed of the recovery winch.

The interval between launch and recovery is simulated by programming a dwell time into the tests. This consists of a pause in rotation of 30 seconds after every $12.2 \mathrm{~m}$ pass of the entire Tamar keel length. This pause not only simulates the dwell between launch and recovery but also allows the dissipation of heat build-up effects in the sample.

Tests are conducted for a total of 1000 passes, corresponding to roughly 10 years of use (based on a weekly launch/recovery). The test is extended beyond the slipway panel design life in order to generate significant wear to ensure accurate measurement following the indications of very low wear coefficients from the reciprocating tribometer tests.

\section{Wear Theory}

Wear of polymers is usually a combination of fatigue and abrasion, in relatively high modulus materials like the graphite infused jute fibre/phenolic resin composite slipway lining abrasive wear tends to dominate ${ }^{14}$. Wear on the slipway 
panels can be expressed as a function of the contact load and sliding distance to generate a dimensional wear coefficient.

\section{Dimensional Wear Coefficient:}

$$
\mathbf{K}=\mathbf{Q} \mathbf{P}_{\mathbf{y}} / \mathbf{L W}
$$

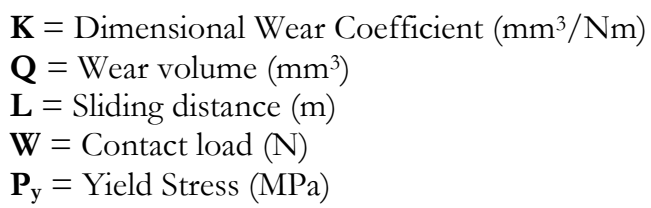

The wear coefficient is used to compare the performance of the slipway linings and lubrication regimes.

\section{Tests Schedule}

Tests are conducted in two stages, first a series of contact force tests are conducted under dry sliding conditions. The slipway panel wear behaviour at high contact pressures is of particular interest as observations from slipway station case studies has indicated a significant increase in wear around areas of panel misalignment where edge stress effects act to increase the apparent pressure on the slipway lining panel.

Secondly, a series of tests using different lubricants are conducted. These aim to evaluate the effects of lubricant choice on minimising the wear on the composite slipways. The lubricants tested are chosen to encompass those currently in use on existing slipways, i.e. no lubricant (dry), marine grease as used on the majority of slipways and a silicon microsphere infused lubricant as used at Sennen Cove and proposed for possible use elsewhere. Also tested are lubricants selected for their environmental performance in order to evaluate their feasibility for slipway use, these are seawater, freshwater and a biodegradeable marine grease. It is hoped that if these eco-friendly greases exhibit sufficient friction and wear performance they may be adopted in place of the lubricants currently used, this would significantly reduce the environmental impact of the accumulated grease around the end of the slipway.

\section{Contact Force Tests:}

Tests are conducted on the jute fibre/phenolic resin composite at contact forces of 20,40, 60 and $80 \mathrm{~N}$ under conditions of dry sliding:

\begin{tabular}{|c|c|c|c|}
\hline Test ID & Lubricant & $\begin{array}{c}\text { Test Duration } \\
\text { (\#passes) }\end{array}$ & $\begin{array}{c}\text { Contact } \\
\text { Pressure (N) }\end{array}$ \\
\hline CR1 & Dry & 1000 & 20 \\
\hline CR2 & Dry & 1000 & 40 \\
\hline CR3 & Dry & 1000 & 60 \\
\hline CR4 & Dry & 1000 & 80 \\
\hline
\end{tabular}

Table. 1. Contact Force Tests

\section{Lubricant Tests:}

Tests are conducted for the following lubrication regimes for a duration of 1000 passes corresponding to the total sliding experienced by the lining during 10 years of service.

\begin{tabular}{|c|c|c|c|}
\hline Test ID & Lubricant & $\begin{array}{c}\text { Test Duration } \\
\text { (\#passes) }\end{array}$ & $\begin{array}{c}\text { Contact } \\
\text { Pressure (N) }\end{array}$ \\
\hline LR1 & Dry & 1000 & 20 \\
\hline LR2 & Seawater & 1000 & 20 \\
\hline LR3 & Freshwater & 1000 & 20 \\
\hline LR4 & Marine Grease & 1000 & 20 \\
\hline LR5 & $\begin{array}{c}\text { Silicon } \\
\text { Microsphere Lub. }\end{array}$ & 1000 & 20 \\
\hline LR6 & Biogrease \#1 & 1000 & 20 \\
\hline
\end{tabular}

Table. 2. Contact Force Tests

\section{Post Test Analysis}

Following the tests the samples are inspected using light microscope and surface profile inferometry techniques to examine the wear scar area. Due to lubricant absorption by the composite and the low wear rates experienced in some cases it is difficult to assess the wear volume using solely mass loss, profile inferometry is used here to assess the wear scar volume and determine the wear coefficient.

\section{Results}

Results are presented below:

\section{Contact Force Tests}

Results from the contact force tests (CR1-4) are shown in figs. 4-5 below. These indicate that the wear is directly proportional to the applied load which would indicate that a real-world increase in contact pressure will correspond to an increase in wear. This has significant implications for slipway panel fitting, from slipway station case studies the panels experiencing the highest wear are noted to be misaligned with respect to their neighbouring panels. This misalignment will result in significant edge stress effects on the slipway panels and a corresponding linear increase in wear as indicated in fig. 4 .

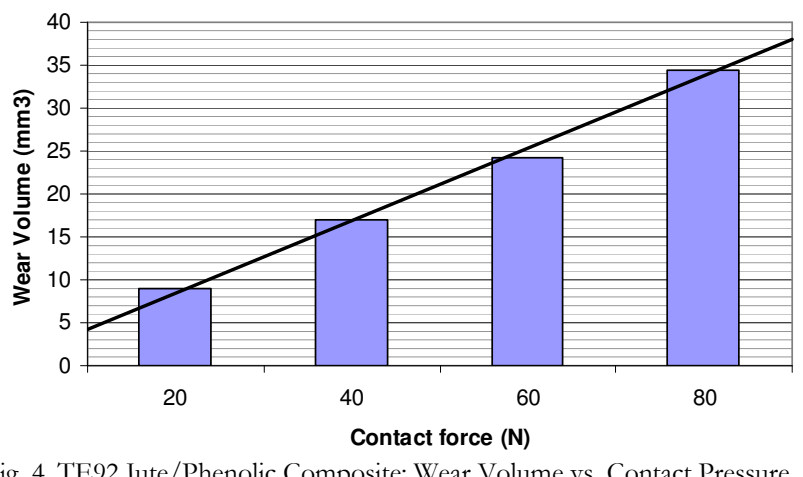

Observed wear coefficients are uniform and very low, indicating that abrasive sliding wear under normal contact pressures would not be sufficient to cause panel failure, even in the case of the composite panels far exceeding their original 2 year lifespan (fig. 5). 


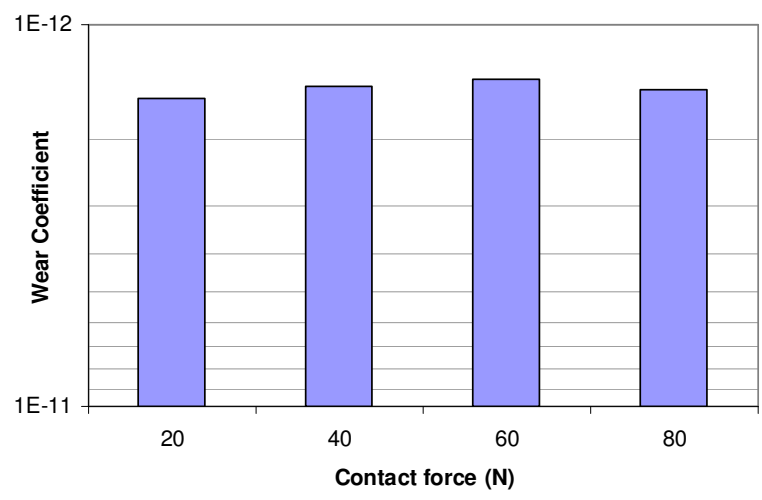

Fig. 5. TE92 Jute/Phenolic Composite: Wear Coefficient vs. Contact Pressure

\section{Lubricant Tests}

The lubricant tests show that the wear observed on the composite samples is greater with the addition of lubricants. This effect is most marked when seawater or freshwater lubrication is used, with only a minor increase in the wear coefficient observed with the marine grease and biogrease lubrication.

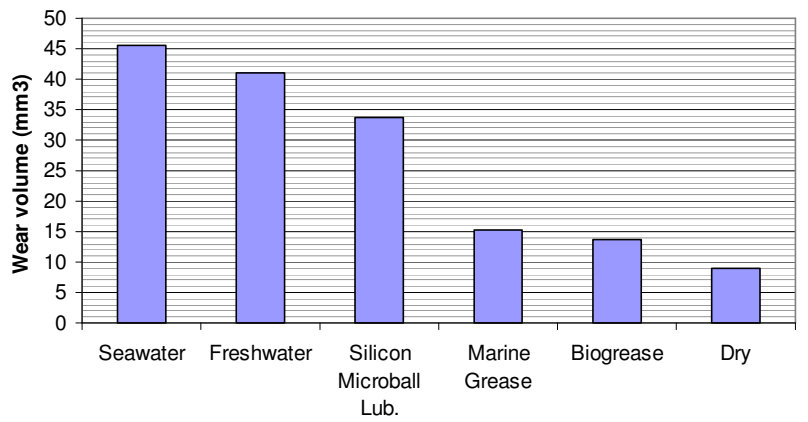

Fig. 6. TE92 Jute/Phenolic Composite: Wear Volume vs. Lubricant Regime

Initially this would seem to suggest that the choice of lubrication is of high importance for minimising the wear along the slipway, however the actual distributed wear scar generated on the slipway in the ideal real world case due to the sliding wear would be less than $1 \mathrm{~mm}$ in all cases, suggesting that the $19 \mathrm{~mm}$ thick composite panel is very unlikely to fail due to abrasive sliding wear regardless of the lubricant used.

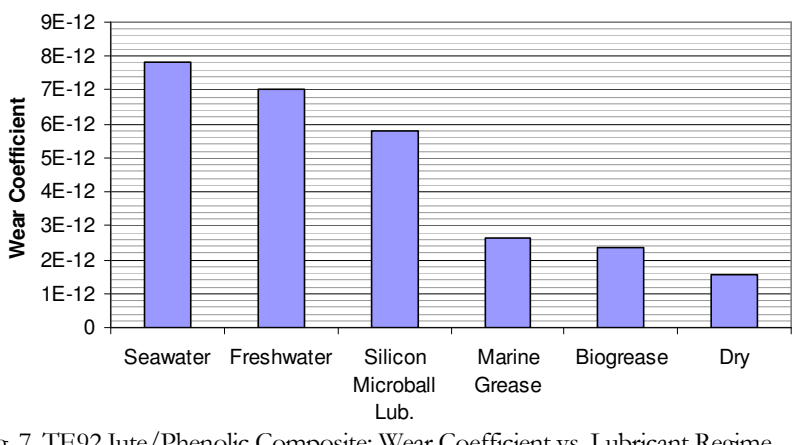

Fig. 7. TE92 Jute/Phenolic Composite: Wear Coefficient vs. Lubricant Regime

\section{Summary}

The rotary tribometer tests conducted here show that the abrasive sliding wear generated under normal conditions would not be sufficient in isolation to cause failure of the slipway panels. Despite this wear is noted as a serious problem on some slipways, particularly the two new boathouses and slipways at Tenby and Padstow. Following this research a closer inspection was made of the slipways in question including a panel wear survey and panel misalignment measurements.

\section{Slipway Panel Survey}

Full surveys of the new slipways at Padstow and Tenby were conducted following the tribometer tests to investigate the real-world failure modes of the slipway panels.

Initial observations indicated that the most severely worn panels were misaligned with respect to their neighbours. It was found that there was significant panel misalignment present along the slipway, most often parallel misalignment, where the panels are vertically displaced from each other at their interface. Skewed misalignment, where the panels are twisted longitudinally to each other was also observed. It was found that the average panel parallel offset was $0.88 \mathrm{~mm}$, with a maximum of over $4 \mathrm{~mm}$. FEA Analysis of the stress concentrations presented by this misalignment from the plane sliding case reveal that stresses can increase to 25 times the perfectly aligned case. The contact pressure tests conducted above indicate a linear relationship between contact pressure and wear and so it would be reasonable to assume that this would also result in a corresponding 25 -fold increase in the wear rate at these high stress regions.

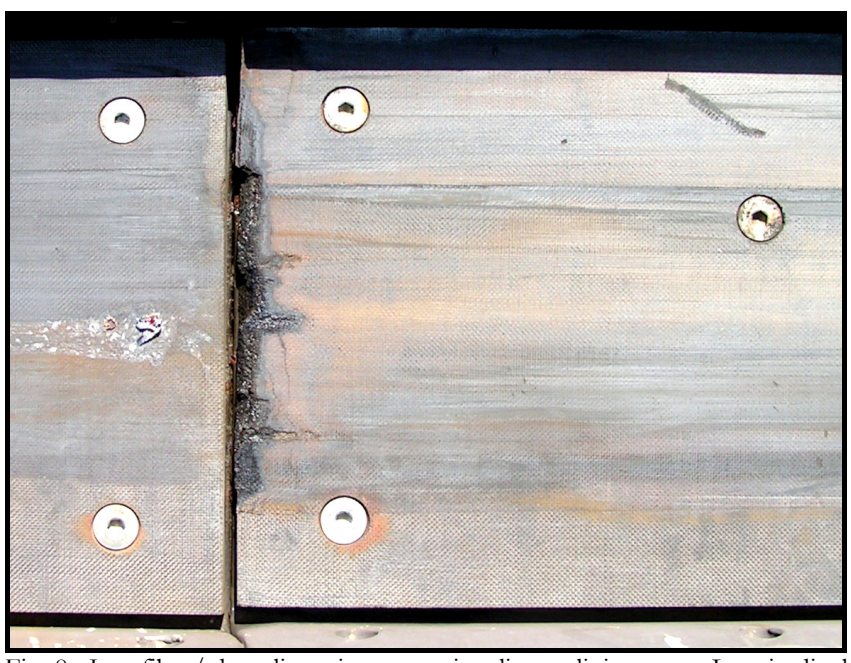

Fig. 8: Jute fibre/phenolic resin composite slipway lining wear: Longitudinal panel edge wear

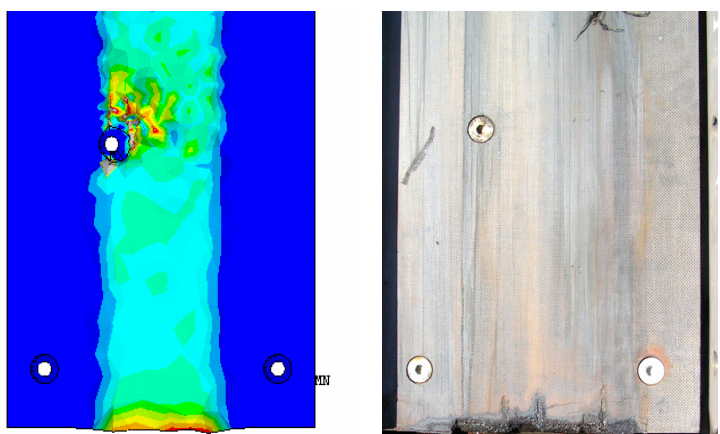

Fig. 9. FEA simulation vs. typical worn and misaligned jute fibre/phenolic resin composite lining section from Tenby slipway

Using the wear coefficients generated above to present a wear scar depth at these stress concentrations it is found that for the seawater lubricated case a wear scar depth equal to the $19 \mathrm{~mm}$ panel thickness and so constituting a panel 
failure will occur after just 17 launches and recoveries. This would support the experience at Tenby where initial slipway hauling trials resulted in 10 launches and recoveries during the trial, this may well have contributed to the subsequent wear failure of slipway panels.

\section{Conclusions}

The tests and slipway surveys conducted above show that while the sliding wear coefficient between the lifeboat keel and the jute/phenolic composite is low enough to cause little cause for concern under ideal sliding conditions, in the real world even slight panel misalignments can result in a serious increase in slipway panel wear. This increase in wear due to panel misalignment would be sufficient to explain the high wear observed at Tenby and Padstow with the introduction of the new Tamar class lifeboat, particularly when the initial extended slipway line trials involving ten or more ascents/descents of the slipway under winch loading are considered. While these would have had little contribution to the wear under ideal conditions, panel misalignments mean that they constitute over $50 \%$ of the number of launches required for the most seriously misaligned panels to fail.

The use of lubricants along the slipway should again have little effect under ideal conditions according to the test data. However, with panel misalignment included the choice of lubricant may become more significant.

\begin{tabular}{|l|c|}
\hline \multicolumn{1}{|c|}{ Lubricant } & $\begin{array}{c}\text { Eq. No of Launches \& Recoveries } \\
\text { for 19mm Wear Scar Depth }\end{array}$ \\
\hline Seawater & 16.80 \\
\hline Freshwater & 18.66 \\
\hline Silicon Microball Lub. & 22.65 \\
\hline Marine Grease & 49.88 \\
\hline Biogrease & 56.30 \\
\hline Dry & 84.58 \\
\hline
\end{tabular}

Table. 3. Equivalent number of lifeboat launches/recoveries required to generate a $19 \mathrm{~mm}$ wear scar on a $4 \mathrm{~mm}$ parallel offset misaligned slipway panel by lubricant used

As can be seen in the table above, the lubricant selection can have a significant impact on the wear rates for a misaligned panel. It should be noted however that previous work using reciprocating tribometers ${ }^{13}$ indicated that for the consistently low friction required for successful lifeboat launch and recovery it is necessary to use some form of lubrication, it is also true that the increased edge stresses associated with panel misalignment will also result in increased friction at these points. For this reason it is more sensible to examine and reduce the causes of slipway panel misalignment than to select a lubricant based on the high wear rates encountered with misaligned panels.

\section{Future Work}

Further study into the friction and wear of slipway lining materials is to be completed but the next stage of research is to further investigate the contributions of keel impact and slipway panel misalignment to the friction and wear conditions on the slipway. Preliminary analysis shows that the friction and wear are proportional to the contact stresses and these are increased in regions of panel misalignment where the contact moves away from the parallel plane on plane case. It is intended that combining the results from the two aspects of this research will present a comprehensive picture of the causes of real-world friction and wear on lifeboat slipways as well as providing a framework for minimising both these effects.

\section{Acknowledgements}

The Authors would like to thank the EPSRC and the RNLI for co-funding this work, and in particular the RNLI for providing support and information throughout the research.

\section{References}

1. Dunn, T, Kennedy, A and Tibbs, J: 'Launching in the 21st Century'. Drydocks Launching and Shiplift, London, UK: 87-91. Royal Institute of Naval Achitects. (2003)

2. Pattison, N, Dixon, $\mathbf{M}$ and Hodder, C: 'Launching and Docking: Experiences at VT Shipbuilding'. Drydocks Launching and Shiplift, London, UK: 35-40. Royal Institute of Naval Achitects. (2003)

3. Clayton Engineering: 'Trial Results: New Tenby Boathouse Winch Instrumented Line Pulls - 10/05/05'. A study for the RNLI (2005)

4. Clayton Engineering: ' 2 nd Instrumented Line Pull Trial Results: New Tenby Boathouse Winch - 10/08/07'. A study for the RNLI (2007)

5. Clayton Engineering: 'Trial Results: New Padstow Boathouse Winch Instrumented Line Pulls - 06/06/06'. A study for the RNLI (2006)

6. RNLI: 'Bembridge Slipway Trial: April 1999'. Internal RNLI Document (1999)

7. RNLI: 'Bembridge Slipway Trial: October 2001'. Internal RNLI Document (2001)

8. Clayton Engineering: 'Instrumented Line Pull Trial Results: Mumbles Boathouse Winch - 10/08/07'. A study for the RNLI (2007)

9. RNLI: 'Selsey Slipway Winch Load \& Keelway Lining Trial Report: March 2002'. Internal RNLI Document (2002)

10. RNLI: 'Selsey Slipway Trial: November 2002'. Internal RNLI Document (2002)

11. Bull, S.J. and Birmingham, R: 'Slip Launched Lifeboats: Materials for Keel and Keelway'. A study for the RNLI (1997)

12. Bull, S.J, Horvathova, K, McNaught, $R$ and Birmingham, R: 'Friction and Wear of alternative Composite Keels for Slip Launched Lifeboats'. A study for the RNLI (1999)

13. Thomas, B, Hadfield, $M$ and Austen S: 'Experimental Wear Modelling of Lifeboat Slipway Launches' Tribology International, 'Duncan Dowson at 80: Proceedings of the 35th 
Leeds-Lyon Symposium on Tribology (Leeds, 2008) Publication pending.

14. Hutchings, I: 'Tribology - Friction and Wear of Engineering Materials', Arnold, p124 (1992)

15. Archard, J.F: 'Contact and Rubbing of Flat Surfaces'. Journal of Applied Physics., 24, p981-8 (1953) 